Benha Veterinary Medical Journal 37 (2019) 149-153

Benha Veterinary Medical Journal
Official Journal Issued by
Faculty of
Veterinary Medicine $\quad$ Journal homepage: https://bvmj.journals.ekb.eg/

Original Paper

\title{
Genotyping and resistance genes of Enterococcus Faecalis isolated from different food sources in Egypt
}

Ashraf A. Abd El-Tawab ${ }^{1}$, Fatma I. El-Hofy ${ }^{1}$, Mohamed A. Abdelmonem², Eman K. Amin ${ }^{1}$

${ }^{1}$ Bacteriology, Immunology and Mycology Department, Faculty of Veterinary Medicine, Benha University, Egypt.

${ }^{2}$ Department of Microbiology, Central Laboratory of Residue Analysis of Pesticides and Heavy Metals in Foods (QCAP), Dokki, Giza, Egypt.

\begin{tabular}{|c|c|}
\hline ARTICLE INFO & ABSTRACT \\
\hline $\begin{array}{l}\text { Received 22/08/2019 } \\
\text { Accepted 23/09/2019 } \\
\text { Availa6le On-Line } \\
\text { 12/05/2020 }\end{array}$ & $\begin{array}{l}\text { Enterococcus species are considered as a major etiological agent of nosocomial infections, they } \\
\text { are commonly isolated from different sources of food. So, this study was conducted for } \\
\text { detection of Enterococcus spp. from fish }(\mathrm{n}=10) \text {, herbs }(\mathrm{n}=30) \text {, drinking water }(\mathrm{n}=20) \text {, dairy } \\
\text { products }(\mathrm{n}=30) \text {, and meat products }(\mathrm{n}=20) \text { samples from Cairo Governorate, Egypt. PCR was } \\
\text { done for detection of some antibiotic resistant genes }(\mathrm{mphC} \text {, norA, tetK, floR, vanA). The results } \\
\text { revealed that from } 110 \text { food samples analyzed, } 11.8 \% \text { were positive for Enterococci. Moreover, } \\
\text { E. faecalis was detected by percentage } 53.8 \% \text {. E. faecalis isolates were resistant to vancomycin } \\
(100 \%) \text {, erythromycin }(57.1 \%) \text {, ciprofloxacin }(14.3 \%) \text {, chloramphenicol }(42.9 \%) \text {, tetracycline } \\
(57.1 \%) \text {, while none of the E. faecalis isolates were resistant to ampicillin, penicillin or } \\
\text { norfloxacin. Genotypic characterization revealed that tet } \mathrm{K} \text { and floR genes were present in the } \\
\text { all } 7 \text { E. faecalis isolates. While, vanA gene was detected in } 3 \text { isolates, and } m p h \text { gene was } \\
\text { detected only in } 2 \text { isolates. The results of our investigation indicated high levels of } \\
\text { contamination with multi-resistant E. faecalis strains of serious concern with the isolation of } \\
\text { strains resistant to vancomycin, considering that vancomycin is the alternative agent for } \\
\text { patients who are intolerant to penicillin or who have Enterococci infections with high level } \\
\text { resistance to penicillin. }\end{array}$ \\
\hline
\end{tabular}

\section{INTRODUCTION}

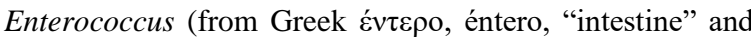
кокко , coccos, "granule") is a large genus of lactic acid bacteria of the phylum Firmicutes (http://www.en.wikipedia.org/Enterococcus_faecalis, 2019). It is normal inhabitant in the gastrointestinal tracts of humans and other mammals. So, it is used as an indicator for faecal contamination and poor hygienic measures during manufacture process of dairy and meat products (Buyukyoruk et al., 2014; Nashy, 2017). Enterococcus can be readily isolated from foods, Once rejected from the environment by means of human faeces or animal ejecta, it is able to colonies diverse niches because of its exceptional aptitude to resist or grow in hostile environments. Therefore, E. faecalis is not only associated with warm-blooded animals, but also occur in soil, surface waters and on plant and vegetables. Also, it can contaminate finished products during food processing (Pesavento et al., 2014; Abdeen et al., 2016).

Enterococci are Gram-positive non-spore forming, catalase and oxidase-negative, facultative anaerobic cocci that often occur in pairs diplococci or short chains (Van Tyne and Gilmore, 2014; Nashy, 2017). Enterococci can tolerate different environmental conditions, such as high temperature, it can grow at temperature ranging from 10-45 ${ }^{\circ} \mathrm{C}$ up to $60{ }^{\circ} \mathrm{C}$ for $30 \mathrm{~min}$, and $\mathrm{NaCl} 6.5 \%$ (Sanlibaba and Senturk, 2018). It can cause life-threatening infections in humans, especially in the nosocomial environment, (Iweribor et al., 2015). Enterococcus spp., particularly E. faecium and E. faecalis, are important in public health. They cause urinary tract infections, bacteremia, peritonitis, and endocarditis in humans (Fisher and Philips, 2009).

Recent studies indicated that the proportion of E. faecalis infections has increased mainly owing to an increased number of antibiotic resistant $E$. faecalis isolates (Golob et al., 2019). E. faecalis is resistant to many commonly used antimicrobial agents (aminoglycosides, aztreonam, cephalosporins, clindamycin, the semisynthetic penicillins nafcillin and oxacillin, and trimethoprimsulfamethoxazole). Resistance to vancomycin in E. faecalis is becoming more common (http://www.en.wiki-pedia.org/ Enterococcus_faecalis, 2019).

In this article, the aim was to provide information about the E. faecalis recovered from selected Egyptian foods, focusing on genotypic characteristics and antibiotic resistance.

\section{MATERIAL AND METHODS}

\subsection{Sampling:}

A total of 110 samples (10 Cray fish , 30 herbs (15 Basil, 10 Camomile, 5 Calendula), 20 water, 30 dairy products (15 milk and 15 cheese), 20 meat products (10 beef burger, and 10 minced meat) were collected randomly from different places and sales markets in Cairo Governorate, Egypt. All The collected samples were labeled, aseptically put into

\footnotetext{
* Corresponding author: Ashraf A. Abd El-Tawab. Bacteriology, Immunology and Mycology Department, Faculty of Veterinary Medicine, Benha University, Egypt.
} 
clean, dry, and sterile containers, kept in ice box and transferred to the laboratory of microbiology to be analyzed for detection and isolation of Enterococcus faecalis.

\subsection{Isolation of Enterococcus: (NMKL 125, 2005; ISO} 7218, 2013; ISO 6887-1, 2017)

For water samples, $100 \mathrm{ml}$ of water sample was filtrated using membrane filter with vacuum pump; the membrane filter was placed on Enterococcus agar (Slantz and Bartley agar). Then, it was incubated at $44 \pm 1{ }^{\circ} \mathrm{C}$ for $48 \mathrm{~h}$ then the membrane was examined for all characteristic colonies.

For solid samples, $10 \mathrm{~g}$ of each sample were mixed with 90 $\mathrm{ml}$ maximum recovery diluents to prepare the initial suspension. By mean of a sterile pipette $1 \mathrm{ml}$ of the initial suspension was transferred to $9 \mathrm{ml}$ of maximum recovery diluents to make serial dilution.

For milk samples, $10 \mathrm{ml}$ of the samples were centrifugated at $5000 \mathrm{rpm}$ for $10 \mathrm{~min}$ and the supernatant was discarded. A loopful of homogenates was plated on the surface of medium.

By using sterile pipette $0.1 \mathrm{ml}$ was added to a sterile Petri dish containing Enterococcus agar. The plate was inverted and incubated at $44 \pm 1{ }^{\circ} \mathrm{C}$ for $48 \mathrm{~h}$. Enterococcus are indicated by all raised colonies with a dark red color, confirmed by inoculation on bile-aesculin agar, incubated at $44 \pm 1{ }^{\circ} \mathrm{C}$ for 2 hours, and read immediately. All typical colonies showed a tan to black color in the surrounding medium.

2.3. Molecular detection of E. faecalis isolates and resistance genes:

Genomic DNA of the isolates were extracted using DNA Purification Kit QIAamp DNA Mini Kit (Cat. No. 51304Qiagen) according to Sambrook et al. (1989) with modification. Determination of Enterococci at genus level was performed using specific gene primers as shown in table 1. The presence of antibiotic resistance genes was identified by PCR in isolated strains.

Table 1 Oligonucleotide primers sequences for detection of E. faecalis and resistance genes

\begin{tabular}{|c|c|c|c|c|}
\hline Gene & & er Sequence & $\begin{array}{l}\text { Amplifie } \\
d\end{array}$ & Reference \\
\hline 16SrRNA & $\begin{array}{l}\mathrm{F} \\
\mathrm{R}\end{array}$ & $\begin{array}{l}\text { GTT TAT GCC GCA TGG CAT AAGAG } \\
\text { CCG TCA GGG GAC GTT CAG }\end{array}$ & $310 \mathrm{bp}$ & $\begin{array}{l}\text { Zoletti et } \\
\text { al. (2006) }\end{array}$ \\
\hline$m p h \mathrm{C}$ & $\begin{array}{l}\mathrm{F} \\
\mathrm{R}\end{array}$ & $\begin{array}{l}\text { GAGACTACCAAGAAGACCTGACG } \\
\text { CATACGCCGATTCTCCTGAT }\end{array}$ & 722 bp & $\begin{array}{l}\text { Schlegelov } \\
\mathrm{a} \quad e t \text { al. } \\
(2008)\end{array}$ \\
\hline nor $\mathrm{A}$ & $\mathrm{F}$ & $\begin{array}{l}\text { TTCACCAAGCCATCAAAAAG } \\
\text { CTTGCCTTTCTCCAGCAATA }\end{array}$ & 620 bp & $\begin{array}{l}\text { Pourmand } \\
\text { et al. } \\
(2014)\end{array}$ \\
\hline tet $\mathrm{K}$ & $\begin{array}{l}\mathrm{F} \\
\mathrm{R}\end{array}$ & $\begin{array}{l}\text { GTAGCGACAATAGGTAATAGT } \\
\text { GTAGTGACAATAAACCTCCTA }\end{array}$ & 360 bp & $\begin{array}{l}\text { Duran et al. } \\
\text { (2012) }\end{array}$ \\
\hline$f l o \mathrm{R}$ & $\begin{array}{l}F \\
R\end{array}$ & $\begin{array}{l}\text { TTTGGWCCGCTMTCRGAC } \\
\text { SGAGAARAAGACGAAGAAG }\end{array}$ & 494 bp & $\begin{array}{l}\text { Doublet et } \\
\text { al. (2003) }\end{array}$ \\
\hline $\operatorname{van} \mathrm{A}$ & $\begin{array}{l}\mathrm{F} \\
\mathrm{R}\end{array}$ & $\begin{array}{l}\text { CATGACGTATCGGTAAAATC } \\
\text { ACCGGGCAGRGTATTGAC }\end{array}$ & 885 bp & $\begin{array}{l}\text { Patel et al. } \\
\text { (1997) }\end{array}$ \\
\hline
\end{tabular}

\subsection{Antibiotic susceptibility:}

Only $E$. faecalis isolates were tested for their susceptibility to 8 antimicrobials by a disk diffusion technique (CLSIM100, 2018). The 8 antibiotics tested comprised fluoroquinolones (ciprofloxacin $5 \mathrm{mg}$, and norfloxacin 10 $\mathrm{mg}$ ), glycopeptides (vancomycin $30 \mathrm{mg}$ ), macrolides (erythromycin $15 \mathrm{mg}$ ), penicillin (ampicillin $10 \mathrm{mg}$, and penicillin $10 \mathrm{mg}$ ), tetracyclines \{tetracycline $(30 \mathrm{mg})$, and phenicols (chloramphenicol (30 mg).

\section{RESULTS}

3.1. Isolation and detection of E. faecalis isolates:

Out of examination of 110 food samples, only 13 samples were positive for enterococcus species. E. faecalis was detected by using specific gene primers as shown in figure (1). Only 7 out of the 13 samples were considered as $E$. faecalis with percent $53.8 \%$ (Table 2).

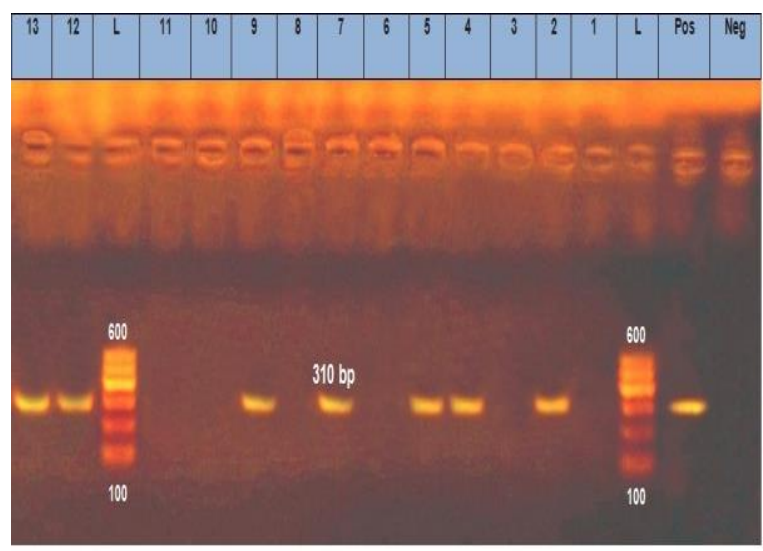

Fig. 1 Gel electrophoresis for molecular identification of E. faecalis. Lane L: molecular weight marker (100-600 bp), Lane pos: positive control, Lane neg: negative control, Lane $(2,4,5,7,9,12,13)$ : are positive isolates.

Table 2 Prevalence of Enterococcal spp. in different food sources in Egypt. Percentage in this table as 1 from $10(100 \%)$ isn't correct

\begin{tabular}{lccccc} 
Percentage in this table as 1 from 10 & \multicolumn{2}{c}{$(100 \%)$ isn't correct } \\
\hline Food Source & Samples & \multicolumn{2}{c}{ No. of } & \multicolumn{2}{c}{ E. faecalis ${ }^{*}$} \\
& & No. & $\%$ & No. & $\%$ \\
\hline Cray fish & 10 & 1 & 10 & 1 & 100 \\
Camomile & 10 & 3 & 30 & 1 & 33.3 \\
Calendula & 5 & 1 & 20 & 1 & 100 \\
Basil & 15 & 1 & 6.7 & 0 & 0 \\
Water & 20 & 5 & 25 & 2 & 40 \\
Beef burger & 10 & 2 & 20 & 2 & 100 \\
Milk & 15 & 0 & 0 & 0 & 0 \\
Cheese & 15 & 0 & 0 & 0 & 0 \\
Total & 110 & 13 & 11.8 & 7 & 53.8 \\
\hline * The percentage of E. faecalis was estimates according to total number of positive \\
isolates.
\end{tabular}

\subsection{Antimicrobial sensitivity test:}

The sensitivity test of seven E. faecalis isolates from cray fish, cammomile, calendula, water, and beef burger samples were done against eight different antimicrobial agents. According to the readings of inhibitory zones of different antibiotic discs on seven E. faecalis isolates, the results clearly shows that the all tested isolates showed multiresistance to different antibiotics. All the 7 isolates were resistant to vancomycin, but they were sensitive to ampicillin and penicillin as shown in table (3).

\subsection{Detection of resistance genes of E. faecalis.}

A PCR was designed to detect tet $\mathrm{K}$ for tetracyclines, flor $\mathrm{R}$ for chloramphenicol, $m p h \mathrm{C}$ for macrolides, nor A for quinolones, and van A for vancomycin genes in seven antibiotic resistant $E$. faecalis as shown in figures (2-5).

The results showed that all the isolates $(100 \%)$ had a band compatible with tet $\mathrm{K}$ and flor $\mathrm{R}$, while only two isolates 
(28.57\%) had a band compatible with $m p h \mathrm{C}$ and only three isolates $(42.86 \%)$ had a band compatible with van $\mathrm{A}$

Table 3 The antibiogram of E. faecalis isolates according to CLSI-M100 (2018)

\begin{tabular}{lccccccc}
\hline \multirow{2}{*}{ Antibiotic Discs } & \multicolumn{7}{c}{ Sample ID } \\
\hline Vancomycin, $30 \mu \mathrm{g}$ & 2 & 4 & 5 & 7 & 9 & 12 & 13 \\
Erythromycin, $15 \mu \mathrm{g}$ & $\mathrm{R}$ & $\mathrm{R}$ & $\mathrm{R}$ & $\mathrm{R}$ & $\mathrm{R}$ & $\mathrm{R}$ & $\mathrm{R}$ \\
Ciprofloxacin, $5 \mu \mathrm{g}$ & $\mathrm{R}$ & $\mathrm{S}$ & $\mathrm{R}$ & $\mathrm{R}$ & $\mathrm{R}$ & $\mathrm{I}$ & $\mathrm{I}$ \\
Chloramphenicol, $30 \mu \mathrm{g}$ & $\mathrm{S}$ & $\mathrm{I}$ & $\mathrm{S}$ & $\mathrm{I}$ & $\mathrm{R}$ & $\mathrm{S}$ & $\mathrm{S}$ \\
Tetracyclin, $30 \mu \mathrm{g}$ & $\mathrm{R}$ & $\mathrm{R}$ & $\mathrm{S}$ & $\mathrm{I}$ & $\mathrm{R}$ & $\mathrm{S}$ & $\mathrm{I}$ \\
Norfloxacin, $10 \mu \mathrm{g}$ & $\mathrm{R}$ & $\mathrm{S}$ & $\mathrm{S}$ & $\mathrm{S}$ & $\mathrm{R}$ & $\mathrm{R}$ & $\mathrm{R}$ \\
Ampicillin, $10 \mu \mathrm{g}$ & $\mathrm{I}$ & $\mathrm{I}$ & $\mathrm{S}$ & $\mathrm{I}$ & $\mathrm{I}$ & $\mathrm{S}$ & $\mathrm{S}$ \\
Penicillin, $10 \mu \mathrm{g}$ & $\mathrm{S}$ & $\mathrm{S}$ & $\mathrm{S}$ & $\mathrm{S}$ & $\mathrm{S}$ & $\mathrm{S}$ & $\mathrm{S}$ \\
\hline
\end{tabular}

Where: R: Resistant. S: Susceptible. I: Intermediate.

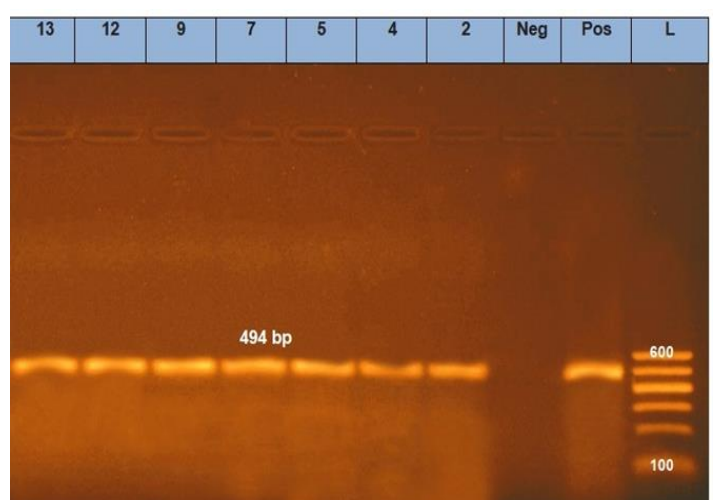

Fig. 2 Gel electrophoresis for floR gene of $E$. faecalis Lane L: molecular weight marke (100-600 bp), Lane pos: positive control, Lane neg: negative control, Lane $(2,4,5,7,9$, 12, 13): are positive.

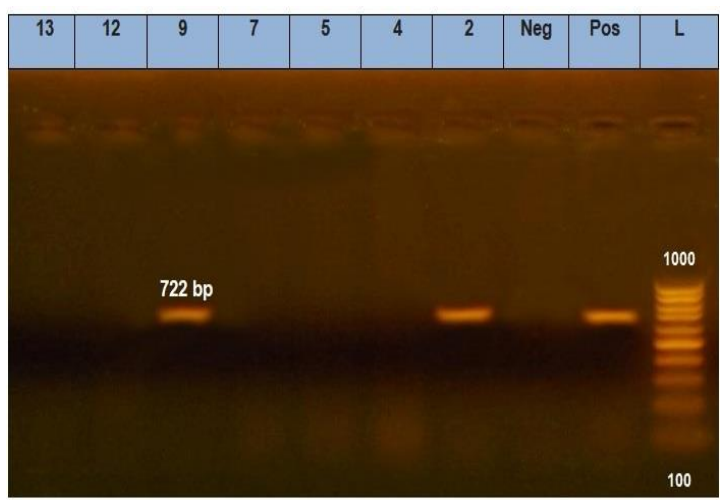

Fig. 3 Gel electrophoresis for $m p h \mathrm{C}$ gene of $E$. faecalis. Lane L: molecular weight marke (100-1000 bp), Lane pos: positive control, Lane neg: negative control, Lane $(2,9)$ : are positive.

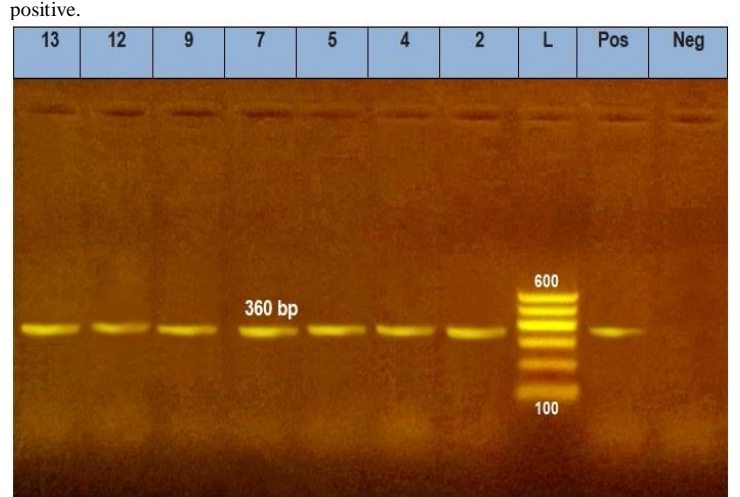

Fig. 4 Gel electrophoresis for tetK gene of E. faecalis. Lane L: molecular weight marker $(100-600$ bp), Lane pos: positive control, Lane neg: negative control, Lane $(2,4,5,7,9$, 12, 13): are positive.

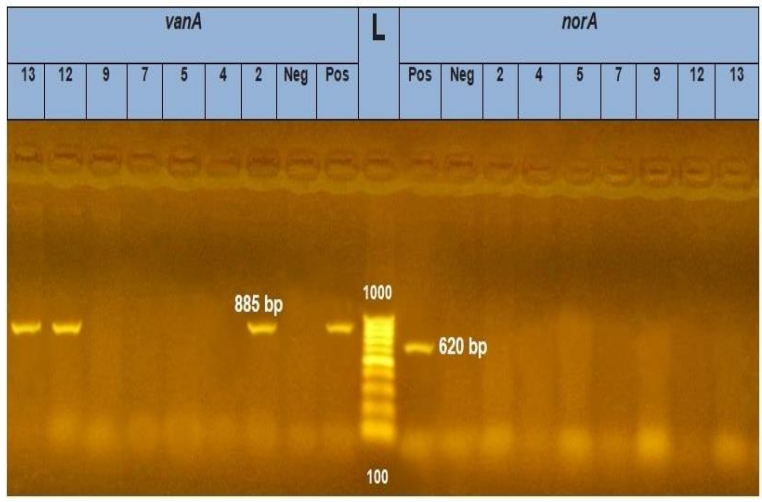

Fig. 5 Gel electrophoresis for $\operatorname{van} \mathrm{A}$ and nor A genes of E. faecalis. Lane L: molecula weight marker (100-1000 bp), Lane pos: positive control, Lane neg: negative control, Lan $(2,12,13)$ : are positive for $\operatorname{van} A$ gene

\section{DISCUSSION}

Enterococci are ubiquitous in nature, exist at high levels in food and can cause severe diseases in humans. They represent one of the leading agents of nosocomial infections especially urinary tract infections in hospitalized patients (Kafil and Asgharzadch, 2014). Enterococci resist to adverse environmental conditions such as low $\mathrm{pH}$, high salinity and high temperatures. So, this takes account for their ability to colonize different habitats and for their potential for easy spreading through the food chain (Fracalanzza et al., 2007). In recent years, Enterococci developed resistance to multiple anti-microbial drugs. Antibiotic resistance may be considered to be both the cause and the effect of the adaptation of certain isolates to hospital environment (Cosentino et al., 2010). Therefore, this study aimed to characterize the spread of some antibiotic resistant genes among Enterococcus faecalis isolates from different food samples (tet $\mathrm{K}$, flo $\mathrm{R}, m p h \mathrm{C}$, nor A, van $\mathrm{A}$.

The classical microbiological techniques currently in use for Enterococcal detection and identification are satisfactory in most situations, and the ability to grow on bile esculin agar. Interestingly, Enterococci naturally determine their frequent finding in food as contaminants. Enterococci can also contaminate finished products, such as fermented food (yogurt and sausages) (Kučerová et al., 2009).

The incidence of Enterococcus among the examined samples was 13 out of 110 with percentage $11.8 \%$, (Cray fish, Basil, Camomile, Calendula, Water, and beef burger were $10 \%, 6.7 \%, 30 \%, 20 \%, 25 \%$, and $20 \%$ respectively), which was close to that reported in Assuit, Egypt (8\%) (Moustafa et al., 1975). While it was lower than that obtained in Menofia, Egypt (75\%) (Abdeen et al., 2016), and in Sharkia and Dakahlia, Egypt (59\%) (Nashy, 2017). in the current work, Genus-specific gene of E. faecalis was detected in only 7 samples out of the 13 Enterococcal isolates by PCR with percentage $53.8 \%$.

The total percentage of E. faecalis isolates agreed with the results isolated from dairy products in Pakistan (57\%) (Javed et al., 2010). While it was higher than that isolated in Brazil $(26.8 \%)$ from fresh herbs, vegetables, meat and dairy products (Gomes et al., 2008), Italy (13.9\%) from retailed products (as cheese, ham, and ready to eat salads) (Pesavento et al., 2014), Japan (32.2\%) from raw fish (Hammad et al., 2014), Tunisia-(27.3\%) from fermented food and vegetable products (Rehaiem et al., 2016), and China (15.3\%) from 
different water samples (Wei et al., 2017). Also, Mcgowanspicer et al. (2008) in Athens, isolated E. faecalis from 23 samples of fresh vegetables and fruits, as well as it was isolated from 55 (vegetables, raw meat and dairy products) samples in Porto Alegre, South Brazil by Medeiros et al. (2014)

As mentioned in table (2), E. faecalis isolates were isolated from different food sources with a percentage of $100 \%$, which was highly predominated in both raw fish and meat, followed by $40 \%$ in both fresh herbs and water. The higher prevalence rate of $E$. faecalis was obtained from raw fish and meat samples $(100 \%)$, which was higher than those of previous studies reported the occurrence of E. faecalis isolated from fresh meat in both Italy $(44.3 \%)$ (Pesavento $e t$ al., 2014), and Brazil (15\%) (Gomes et al., 2008). As well as E. faecalis isolated from fresh fish in Japan (32.2\%) (Hammad et al., 2014). The incidence of E. faecalis in fresh herbs samples (40\%), which was higher than that obtained in Brazil (2.5\%) (Gomes et al., 2008). On the other hand, the incidence of E. faecalis in water samples (40\%), which is lower than that obtained in China $(57.1 \%$ ) (Wei et al., 2017).

One of the most important concerns regarding the presence of $E$. faecalis in the food chain is the possible transmission of antibiotic resistance (Franz et al., 2001). Indeed, this bacterium has a remarkable ability to acquire new mechanisms of resistance and can also transfer resistance determinants to other bacteria by conjugation (Sanlibaba and Senturk, 2018; Sanlibaba et al., 2018; Golob et al., 2019). Antibiotic-resistant E. faecalis are widespread in meat products, dairy products, and ready-to-eat foods (Pesavento et al., 2014; Rehaiem et al., 2016).

In our study the in vitro sensitivity tests of 7 E. faecalis isolates revealed that the tested isolates were resistant to vancomycin $(100 \%)$, erythromycin $(57.1 \%)$, ciprofloxacin $(14.3 \%)$, chloramphenicol $(42.9 \%)$, tetracycline $(57.1 \%)$, while, none of the E. faecalis isolates were resistant to ampicillin, penicillin or norfloxacin. in El-Menofia Governorate, Egypt. Hammad et al. (2015) stated that most of samples were resistant to vancomycin, erythromycin, ciprofloxacin, chloramphenicol and tetracycline with percentage $62.5 \%, 12.5 \%, 37.5 \%, 12.5 \%$ and $62.5 \%$, respectively. While, the results of studies of resistance to antibacterial agents of $E$. faecalis, which were isolated from raw milk and cottage cheese in Ukraine by Horiuk et al. (2018) were compatible with current results in the resistant to vancomycin $(79.5 \%)$ and tetracycline $(77.1 \%)$, but different in their resistance to both norfloxacin $(52.1 \%)$ and ampicillin $(27.1 \%)$. Significant differences in rates of multiple-drug resistant $E$. faecalis detection were observed for different countries which could be due to the different regulations and policies pertaining to antibiotic use in animals, the sensitivity of detection methods, number and kinds of examined samples (Gulhan et al., 2015; Rehaiem et al., 2016).

\section{CONCULOSION}

From this study we can conclude that, the high degree of contamination of most foods analyzed is an indicator of how high the probability of colonization by these microorganisms of the human intestine. Enterococci, however, do not represent a serious risk to the immunocompetent population and should be considered not only as potential pathogens, but also as a reservoir of genes encoding for antibiotic resistance that can be transferred to other pathogenic and nonpathogenic microorganisms. Moreover, considering that Enterococcus spp. isolated from foods and clinical samples, are becoming resistant to an increasing number of antibiotics.

\section{REFERENCES}

1. Abdeen E.E., Hussien H., Hussan Z., Abdella W., (2016), Genotyping and virulence genes of Enterococcus faecalis isolated from kareish cheese and minced meat in Egypt. Research Journal of Microbiology, 11 (4-5): 133-138.

2. Buyukyoruk S., ayaz N.D., Geneay Y.E., Beyaz D, Kocak P., (2014), Species distribution, molecular characteristics and vancomycin resistance gene profiles of Enterococcus spp. isolates from farmhouse cheeses in western Turkey. International Journal of Dairy Technology, 67 (1): 103-109.

3. CLSI- M100 (2018), Performance standard for antimicrobial susceptibility testing-Table (2D): Zone diameter and MIC breakpoints for Enterococcus spp., Clinical and Laboratory Standards Institute, $28^{\text {th }}$ Edition, 38 (3): 64-67.

4. Cosentino S., Podda G.S., Corda A., Fadda M.E., Deplano M., Pisano M.B., (2010), Molecular detection of virulence factors and antibiotic resistance pattern in clinical Enterococcus faecalis strains in Sardinia. Journal of Preventive Medicine and Hygiene, 51: 31-36.

5. Fisher K., Phillips C., (2009), The ecology, epidemiology, and virulence of Enterococcus, Microbiology, 155: 1749-1757.

6. Fracalanzza S.A., Scheidegger E.M., Santos P.F., Leite P.C., Teixeira L.M., (2007), Antimicrobial resistance profiles of Enterococci isolated from poultry meat and pasteurized milk in Rio de Janeiro, Brazil, Mem Inst. Oswald Cruz, 102 (7): 853-859

7. Franz C.M.A.P., Muscholl-Silberhorn A.B., Yousif N.M.K Vancanneyt M., Swings J., Holzapfel W.H., (2001), Incidence of virulence factors and antibiotic resistance among Enterococci isolated from food, Applied and Environmental Microbiology, 67 (9): 4385-4389.

8. Golob M., Pate M., Kušar D., Dermota U., Avberšek J., Papić B., Zdovc I., (2019), Antimicrobial resistance and virulence genes in Enterococcus faecium and Enterococcus faecalis from humans and retail red meat, BioMed Research International, 2019: 1-12.

9. Gomes B.C., Esteves C.T., Palazzo I.C.V., Darini A.L.C., Felis G.E., Sechi L.A., Franco B.D.G.M., De Martinis E.C.P. (2008), Prevalence and characterization of Enterococcus spp. isolated from Brazilian foods, Food Microbiology, 25: 668675 .

10. Gulhan T., Boynukara B., Ciftci A., Sogut M.U., Findik A., (2015), Characterization of Enterococcus faecalis isolates originating from different sources for their virulence factors and genes, antibiotic resistance patterns, genotypes and biofilm production, Iranian Journal of Veterinary Research, 16 (3): 261-266

11. Hammad A.M., Shimamoto T., Shimamoto T., (2014), Genetic characterization of antibiotic resistance and virulence factors in Enterococcus spp. From Japanese retail ready-toeat raw fish, Food Microbiology, 38: 62-66.

12. Hammad A.M., Hassan H.A., Shimamoto T., (2015), Prevalence, antibiotic resistance and virulence of Enterococcus spp. in Egyptian fresh raw milk cheese, Food Control, 50: 815-820.

13. Horiuk Y.V., Kukhtyn M.D., Vergeles K.M., Kovalenko V.L., Verkholiuk M.M., Peleno R.A., Horiuk V.V., (2018), Characteristics of Enterococci isolated from raw milk and hand-made cottage cheese in Ukraine, Research Journal of Pharmaceutical, Biological, and Chemical Sciences, 9 (2): 1128-1133.

14. http://www.en.wikipedia.org/wiki/Enterococcus_faecalis, (2019). 
15. ISO 6887-1, (2017), Microbiology of the food chain -Preparation of test samples, initial suspension and decimal dilutions for microbiological examination -- Part (1): General rules for the preparation of the initial suspension and decimal dilutions, International Organization for Standardization (ISO), Geneva, Switzerland, 1-26.

16. ISO 7218/2007 (Amd. 1/2013), Microbiology of food and animal feeding stuffs-General requirements and guidance for microbiological examinations, International Organization for Standardization (ISO), Geneva, Switzerland, 1-26.

17. Iweribor B.C, Obi L.C., Okoh A.L., (2015), Virulence and antimicrobial resistance factors of Enterococcus spp. isolated from fecal samples from piggery farms in Eastern Cape, South Africa, BMC Microbiology, 15 (136): 1-11.

18. Javed I., Ahmed S., Ali M.I., Ahmad B., Ghumro P.B., Abdu Hameed, and Chaudry G.J., (2010), Bacteriocinogenic potential of newly isolated strains of Enterococcus faecium and Enterococcus faecalis from dairy products of Pakistan, Journal of Microbiology and Biotechnology, 20 (1): 153-160.

19. Kafil H.S. and Asgharzadch M., (2014), Vancomycin resistant Enterococcus faecium and Enterococcus faecalis isolated from education hospital of Iran, Maedica (Buchar), 9 (4): 323 327.

20. Kučerová K., Svobodová H., Tuma S., Ondráčková I, Plocková M., (2009), Production of biogenic amines by Enterococci, Czech Journal of Food Science, 27 (2): 50-55.

21. McGowan-Spicer L.L., Fedorka-Cray P.J., Frye J.G., Meinersmann R.J., Barrett J.B., Jackson C.R., (2008), Antimicrobial resistance and virulence of Enterococcus faecalis isolated from retail food, Journal of Food Protection, 71 (4): 760-769.

22. Medeiros A.W., Pereira R.I., Oliveira D.V., Martins P.D., d'Azevedo P.A., Van der Sand S., Frazzon J., Frazzon A.P.G., (2014), Molecular detection of virulence factors among food and clinical Enterococcus faecalis strains in South Brazil, Brazilian Journal of Microbiology, 45 (1): 327-332.

23. Moustafa T.H., Kamel Y.Y., Ahmed A.A., Ismail A.A., (1975), Studies on the sanitary condition of market milk in
Assiut province Egypt. II: The incidence of potentially pathogenic microorganisms, Assiut Veterinary Medical Journal, 2 (3/4): 181-191.

24. Nashy E.N.E., (2017), Prevalence of virulence factors in Enterococci isolated from different sources, MVSc. Thesis in Bacteriology, Immunology and Mycology, Faculty of Veterinary Medicine, Benha University.

25. NMKL 125, (2005), Thermotolerant coliform bacteria and Escherichia coli. Enumeration in food and feed, $4^{\text {th }}$ Edition, Nordic Committee on Food Analysis (NMKL).

26. Pesavento G., Calonico C., Ducci B., Magnanini A., Lo Nostro A., (2014), Prevalence and antibiotic resistance of Enterococcus spp. isolated from retail cheese, ready-to-eat salads, ham, and raw meat, Food Microbiology, 41: 1-7.

27. Rehaiem A., Fhoula I., Slim A.F., Boubaker I.B.B., Chih A.B., Ouzari H.I., (2016), Prevalence, acquired antibiotic resistance and bacteriocin production of Enterococcus spp. isolated from Tunisian fermented food products, Food Control, 63: 259-266.

28. Sambrook J., Fritscgh E.F., Mentiates, (1989), Molecular coloning - A laboratory manual, Vol (1), Cold Spring Harbor Laboratory Press, New York.

29. Sanlibaba P. and Senturk E., (2018), Prevalence, characterization and antibiotic resistance of Enterococci from traditional cheeses in Turkey, International Journal of Food Properties, 21 (1): 1955-1963.

30. Sanlibaba P., Tezel B.U., Senturk E., (2018), Antimicrobia Resistance of Enterococcus Species Isolated from Chicken in Turkey, Korean Journal for Food Science of Animal Resources, 38 (2): 391-402.

31. Van Tyne D. and Gilmore M.S., (2014), Friend turned foe: Evolution of Enterococcal virulence and antibiotic resistance, Annual Review of Microbiology, 68: 337-356.

32. Wei L., Wu Q., Zhang J., Guo W., Chen M., Xue L., Wang J., Ma L., (2017), Prevalence and genetic diversity of Enterococcus faecalis isolates from mineral water and spring water in China, Frontiers in Microbiology, 8: 1-8. 